Journal of Southeast Asian

\title{
Book Review: Golden Bones: An Extraordinary Journey from Hell in Cambodia to a New Life in America, by Sichan Siv
}

Monirith Ly

Texas State University, San Marcos, rithly@gmail.com

Follow this and additional works at: https://docs.lib.purdue.edu/jsaaea

\section{Recommended Citation}

Ly, Monirith (2012) "Book Review: Golden Bones: An Extraordinary Journey from Hell in Cambodia to a New Life in America, by Sichan Siv," Journal of Southeast Asian American Education and Advancement. Vol. 7 : Iss. 1, Article 7.

DOI: 10.7771/2153-8999.1049

Available at: https://docs.lib.purdue.edu/jsaaea/vol7/iss1/7

This document has been made available through Purdue e-Pubs, a service of the Purdue University Libraries. Please contact epubs@purdue.edu for additional information.

This is an Open Access journal. This means that it uses a funding model that does not charge readers or their institutions for access. Readers may freely read, download, copy, distribute, print, search, or link to the full texts of articles. This journal is covered under the CC BY-NC-ND license. 


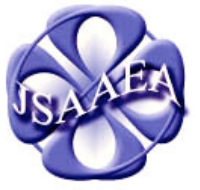

Volume 7 (2012)
Journal of Southeast Asian American Education \& Advancement

WWW.JSAAEA.org
A peer-reviewed scholarly journal published by the National Association for the Education \& Advancement of Cambodian, Laotian, and Vietnamese Americans (NAFEA)

\title{
Siv, Sichan. (2008). Golden Bones: An Extraordinary Journey from Hell in Cambodia to a New Life in America. New York: HarperCollins. 336 pp. \$19.72 (Paperback). ISBN: 978-0-06-134068-0.
}

\author{
Reviewed by \\ Monirith Ly \\ Texas State University
}

Golden Bones is an inspiring autobiography of former White House official, and former U.S. Ambassador to the United Nations, Sichan Siv, a Cambodian American survivor of the Khmer

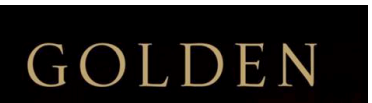
Rouge genocide. Golden Bones, an expression in Khmer, metaphorically means "lucky," and thus represents his remarkable life story, including his escape from the Khmer Rouge in Cambodia to the refugee camps in $\mathrm{BONES}$ An Extroordinary lourney from Hell Iin Cambodia to New Lif in Americe Thailand, and ultimately his rise to prestigious leadership positions representing the White House and the United States internationally.

Siv begins his book by telling readers why he finally decided to write his story. Siv writes his story as a series of flashbacks, presented chronologically and divided into two major episodes: Cambodia and America. His life in each country is further divided into major sections consisting of several chapters describing significant periods, events, and themes in his life. These well-organized divisions help readers move through the story smoothly as if they were watching Siv from birth.

In the first episode, Siv talks about his life beginning with his birth in 1948 into an uppermiddle-class family just outside of Cambodia's capital, Phnom Penh. Siv's father was a district police chief, and his maternal grandfather was a provincial governor. Siv was the youngest in his family, with two older sisters and an older brother. His childhood life "seemed like paradise" (p. 8). With a loving family, he had nothing to worry about. He enjoyed playing with his friends, such as swimming, duck chasing, and toy making.

Tragedy struck early in Siv's life. When he was 9 years old, he lost his father and one of his sisters, due to illness. From early on, his mother had to work hard to support the family, and Siv and his siblings had to help their mother with her few small businesses. Despite these challenges, Siv was admitted to the prestigious Sisowath High School. He was a Boy Scout leader and traveled extensively across Cambodia. These experiences helped him gain valuable knowledge and skills that ultimately would help him survive the genocide and escape from

\section{@)}

SOMERIGHISRESERVED Readers are free to copy, display, and distribute this article, as long as the work is attributed to the author(s) and the Journal of Southeast Asian American Education \& Advancement, it is distributed for noncommercial purposes only, and no alteration or transformation is made in the work. More details of this Creative Commons license are available at http://creativecommons.org/licenses/by-nc-nd/3.0/. All other uses must be approved by the author(s) or JSAAEA. 
Cambodia. In addition, Siv read a lot of Khmer literature and loved to study astronomy, American literature, geography, and history.

After high school, Siv worked as a civil flight attendant. Later, he attended two colleges majoring in English and law. He also completed teacher training and taught English at a high school in Phnom Penh. During Cambodia's war against the Vietcong and the Khmer Rouge in the early 1970s, Siv resigned from his teaching position to join an American relief organization. While the Khmer Rouge began taking over Phnom Penh in April 1975, Siv missed an opportunity to join the American evacuation out of Cambodia via helicopters because he was determined to deliver food and medical supplies to the large number of refugees from the countryside who had poured into the capital to escape the fighting.

On April 17, 1975, the Khmer Rouge captured Phnom Penh and took over the country. Their reign of genocidal terror began immediately as they evacuated the city, sending all residents out into the countryside where they were forced to perform harsh agricultural labor in slave labor camps. Food was scarce, and many died of starvation and disease. Former government officials and members of the educated classes were targets for execution.

After Siv and his family were forced into the countryside, they realized their former highranking positions would put them in danger. Siv's mother told her son that he had to leave, sending him off with a message to "never give up hope." He carefully asked the Khmer Rouge for a three-day pass, claiming that he needed to help his cousin find his family. Over the next several months, Siv managed to go the southeastern part of Cambodia and later set off towards Thailand in the northwest. He had a clever strategy which enabled him to move around the country: writing his own passes and telling the Khmer Rouge he was a driver returning to the next village. The only way to survive was to lie. Near the border, he was once again captured and forced to work long hours with little food. Driven by his mother's words of hope, Siv kept going, waiting for an opportunity to escape into Thailand.

The day finally came: February 13, 1976. Riding on the back of a logging truck, Siv jumped off and ran into the forest. After a long dangerous journey, he eventually reached Thailand successfully! Siv is among a very small group of survivors who managed to escape from the country prior to the fall of the Khmer Rouge in 1979. Thus, his escape is truly remarkable. However, soon after his escape, he was arrested and placed in a Thai prison, as they mistook him for a Khmer Rouge soldier. With the help of his former American colleagues, he was released and transferred to the Wat Koh refugee camp, where he taught English to his fellow refugee survivors. Ultimately, Siv obtained sponsorship to resettle in the United States. Sadly, his family was less fortunate. Years later, Siv would discover that he was the only surviving member of his family.

In the second episode, Siv describes his life in the United States after resettling there in 1976. As a recently arrived refugee, he first began to work as an apple picker. Over the years he worked many different odd jobs, including a stint as a New York City taxi driver. Through hard work and sacrifice, he obtained a graduate scholarship to attend Columbia University. This was a major turning point in Siv's new life. After graduation, Siv had many opportunities to work in the professional and political world. He later became actively involved as a volunteer in the presidential campaign for George H. W. Bush.

After President Bush (Sr.) won the election and took office in 1989, he appointed Siv as his Deputy Assistant for Public Liaison, the first Asian American to ever reach that rank. Siv also became the first Cambodian American to work in the White House. In addition to official correspondence with the public, Siv organized many public events for President Bush, and also 
represented the President at many official events. He often practiced his speeches in front of his wife, Martha Pattillo. His proud, typical opening was "On behalf of the President, ..." He describes his most exciting achievement was sustaining the president's veto over congressional discontinuation of most-favored-nation trade status for China after the violent breakup of demonstrators in 1989. Significantly, his position in the White House enabled Siv to become actively involved in the Cambodian Peace Accords, representing the United States at meetings with world leaders and the leaders of Cambodia's warring factions, to lay out the blueprints for the Cambodian peace process.

In 2001, after George W. Bush took office as President of the United States, Siv was once again called upon to serve his country. President Bush (Jr.) appointed Siv as a U.S. Ambassador to the United Nations Economic and Social Council, a position he held until his retirement in 2005. Golden Bones concludes with Siv and his wife's travel to Thailand, Cambodia, and her hometown in Texas.

Siv's incredible story has been featured in many media broadcasts and news articles. As a Cambodian international graduate student studying in the United States, I was reminded of many of the wonderful Khmer sayings by reading Siv's book. For instance, "You can take a person out of Cambodia; you can't take Cambodia out of him" (p. 312). This represents Siv's pride in his Khmer culture. Siv also notes a disturbing communist Khmer Rouge slogan and philosophy: "There was nothing to be gained by keeping one of us, and nothing to lose by getting rid of one of us" (p. 96). Such a dark philosophy resulted in the genocide of two million people, which is still haunting its survivors. Golden Bones does not just tell Siv's life story, but the story of many Cambodians as it connects with our history and culture. Anyone who has lived through the atrocities will hear their own voices and those of their family members and friends in Siv's story.

In addition, what his mother always taught him is truly meaningful: "No matter what happens, never give up hope." She also taught him, "Without love and hope our lives will be empty. Happiness is something we cannot keep, unless we give it away" (p. 83). Whenever reflecting on his misfortunes, Siv concluded, "It could have been worse." For him, this implies the strength he drew from his mother's words as well as the spirit he carried from his fight to survive and later to his work helping others.

Interestingly, throughout the book Siv managed to infuse many humorous moments that exemplify his character. For example, during the Khmer Rouge period he and his cousin "did not thank [the Khmer Rouge soldier] for the two mangoes that had disappeared from his basket into our pockets" (p. 107). He also mentioned that his first night without a shower was not during his ten months under the Khmer Rouge, but during his flight to the United States. In yet another witty remark, to hide his ripped pants, he told his party hosts he sang better with his jacket on.

Still, the book leaves me with a few questions. I wonder how he got his U.S. Army boots and kept them hidden from Khmer Rouge eyes. As I was born in Cambodia after the genocide, I cannot imagine how 3,500 refugees could fit in a camp as small as one soccer field. As a Cambodian citizen, I greatly appreciate Mr. Siv's diplomatic leadership in helping to bring peace back to Cambodia. His White House and U.N. positions certainly had some influence on the direction of Cambodia, though I wish Siv had given more details in the book about those efforts. I am also curious to know more about his political and philanthropic efforts for Cambodia since 1992. Cambodians need help from such an important, compassionate leader as Sichan Siv. Nonetheless, Siv's love for and commitment to Cambodia is remarkable. Personally speaking, I think that if I had lost as many family members as Siv did in Cambodia under the Khmer Rouge, and escaped to America, I doubt if I would have even given much thought about Cambodia. 
In short, Sichan Siv is truly an admirable person. He risked his life to save Cambodians in a time of crisis, and he held important U.S. positions for many years. He is clever and hardworking. As he often comments proudly on his journey to the White House from being an apple picker and taxi driver, "Only in America!" do you have a chance of reaching such heights. As such, Golden Bones tells the story of a man who escaped from hell, tragically lost all his family, yet achieved his American Dream. With vivid details, Golden Bones is truly an inspiring book for any American, and especially for ambitious Americans from refugee and immigrant backgrounds.

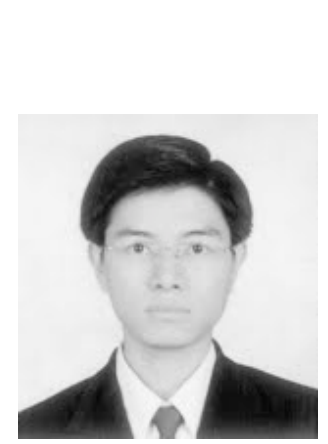

\begin{abstract}
About the Author
Monirith Ly is a Doctoral Candidate in the Adult, Professional and Community Education program at Texas State University. He began his career in higher education as a lecturer at the Royal University of Phnom Penh in 2001 and later became the university's Quality Assurance Officer in 2006. He holds a M.Ed. in Higher Education from Loyola University in Chicago. His current research interests include faculty development and service learning in Cambodian universities.
\end{abstract}




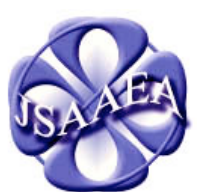

Volume 7 (2012)

\section{Journal of Southeast Asian American Education \& Advancement}

\author{
WwW.JSAAEA.org
}

\section{Editor}

Dr. Wayne E. Wright

University of Texas, San Antonio

\author{
Associate Editors \\ Dr. Chhany Sak-Humphry \\ University of Hawaii at Manoa
}

Dr. Phitsamay Sychitkokhong Uy

University of Massachusetts, Lowell

\section{Book Review Editor}

Dr. Vichet Chhuon

University of Minnesota

\section{Creative Works Editor \\ Bryan Thao Worra \\ Lao Assistance Center}

Special Advisor

Gregory Green

Curator, Echols Collection on Southeast Asia, Cornell University Library

\author{
Journal Manager \\ Sovicheth Boun \\ University of Texas, San Antonio
}

A peer-reviewed scholarly journal published by the

National Association for the Education \& Advancement of Cambodian, Laotian, and Vietnamese

Americans (NAFEA)

Comments and questions for the editorial staff may be directed to jsaaea@lists.sis.utsa.edu

\section{Editorial Review Board}

\author{
Dr. Steve Arounsack \\ California State University, Stanislaus \\ Dr. Phala Chea \\ Lowell Public Schools \\ Dr. Loan Dao \\ Cancer Prevention Institute of California \\ Dr. Sophal Ear \\ U.S. Naval Postgraduate School \\ Dr. Nancy H. Hornberger \\ University of Pennsylvania \\ Dr. Peter Nien-Chu Kiang \\ University of Massachusetts, Boston
}

Dr. Carl L. Bankston III

Tulane University

Dr. George Chigas

University of Massachusetts, Lowell

Dr. Changming Duan

University of Missouri, Kansas City

Dr. Jeremy Hein

University of Wisconsin - Eau Claire

Dr. Samlong Inthaly

Minneapolis Public Schools

Dr. Kevin K. Kumashiro

University of Illinois, Chicago 


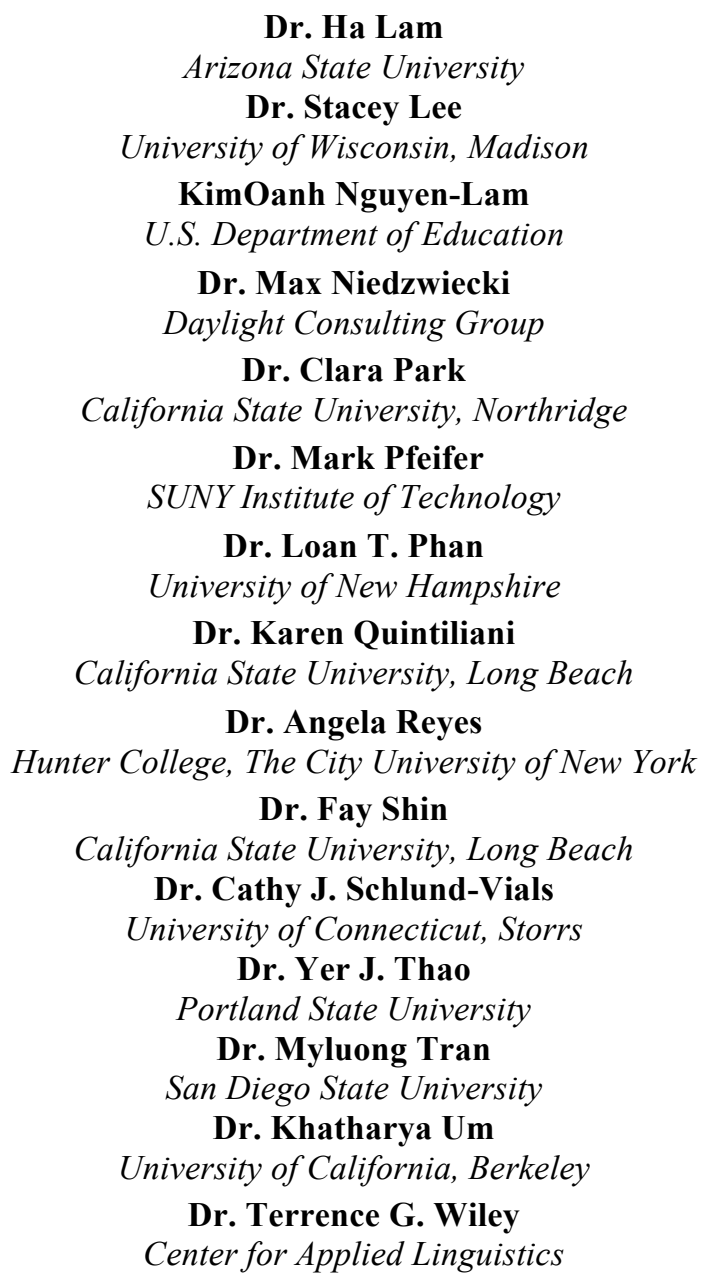

\section{Doctoral Student Editorial Review Board}

\author{
Keo Chea-Young \\ University of Pennsylvania \\ Ketmani Kouanchao \\ California State University, Fullerton \\ Ravy Lao \\ University of California, Santa Barbara \\ Thien-Huong Ninh \\ University of Southern California \\ Vanna Som \\ Harvard University \\ Krissyvan Truong \\ Claremount Graduate University \\ Yang Sao Xiong \\ University of California, Los Angeles
}

\author{
Annie BichLoan Duong \\ San Joaquin County Office of Education \\ Peter Tan Keo \\ Columbia University \\ Monirith Ly \\ Texas State University-San Marcos \\ Malaphone Phommasa \\ University of California, Santa Barbara \\ Alisia Tran \\ University of Minnesota \\ Silvy Un \\ University of Minnesota \\ Yeng Yang \\ University of Texas, San Antonio
}

